\title{
Nitrous Oxide Release from Poultry and Pig Housing
}

\author{
Jan Broucek* \\ National Agricultural and Food Centre, Research Institute of Animal Production Nitra, \\ 95141 Luzianky, Slovakia
}

Received: 7 June 2017

Accepted: 12 July 2017

\begin{abstract}
The article investigates the scientific literature regarding $\mathrm{N}_{2} \mathrm{O}$ emissions according to housing and manure management in poultry and pig buildings. The majority of the $\mathrm{N}_{2} \mathrm{O}$ is emitted from manure storages and housing space, with small amounts emitted from the surface of passages. Many factors must be considered in successful emission evaluation, including season of the year, amount and depth of the bedding, animal density, type and floor space, feeding and watering practices, ventilation, temperature, and relative humidity. The liquid manure from poultry housing systems produces greater emissions of $\mathrm{N}_{2} \mathrm{O}$ than natural and force-dried manure. The influencing factors appeared to be manure removal frequency and the dry matter content of the manure. There are more housing types in pig barns, which differ in bedding, floor, and manure deposition. The highest $\mathrm{N}_{2} \mathrm{O}$ emissions were found in the sawdust bedding, and $\mathrm{N}_{2} \mathrm{O}$ production in slatted floor housing is lowest. This paper reports on technical options for mitigating emissions from poultry and swine contributions. The actual rate of $\mathrm{N}_{2} \mathrm{O}$ emission is highly dependent on the management strategies implemented on a farm. Consequently, improvements in management practices will affect future $\mathrm{N}_{2} \mathrm{O}$ emissions. Finally, emission factors are listed in a table.
\end{abstract}

Keywords: environment, emissions, greenhouse gas, housing, bedding, manure

\section{Introduction}

Gaseous nitrogen compounds $\left(\mathrm{NO}_{x}, \mathrm{~N}_{2} \mathrm{O}\right)$ are known to cause severe environmental problems. $\mathrm{NO}_{\mathrm{x}}$ promotes ozone formation in the troposphere, and nitrous oxide $\left(\mathrm{N}_{2} \mathrm{O}\right)$ is a greenhouse gas that contributes to the reduction of ozone in the stratosphere through the photochemical decomposition of $\mathrm{N}_{2} \mathrm{O}$ to $\mathrm{NO}$ [1-5].

This gas is produced during several microbial processes in the nitrogen $(\mathrm{N})$ cycle of terrestrial and aquatic systems [6]. Animal husbandry practices can have a large impact on the emission of $\mathrm{N}_{2} \mathrm{O}$. They

*e-mail: broucek@vuzv.sk,jbroucek@hotmail.com potentially contribute up to $50 \%$ of total agricultural $\mathrm{N}_{2} \mathrm{O}$ emissions [7]. Emissions from farms are particularly due to the intensive nitrogen cycle [8-9]. The non-ruminant sector is a minor $\mathrm{N}_{2} \mathrm{O}$ emissions contributor compared with ruminant $\mathrm{N}_{2} \mathrm{O}$ emissions. The poultry industry is the largest direct $\mathrm{N}_{2} \mathrm{O}$ producer of the non-ruminant livestock industries, contributing $92.8 \%$ of the total non-ruminant $\mathrm{N}_{2} \mathrm{O}$ emissions [10]. In pig houses, $\mathrm{N}_{2} \mathrm{O}$ originates only from manure [11].

Nitrous oxide is primarily produced through nitrification and denitrification processes in nitrogencontaining substances such as agricultural soils and via digestion of organic matter in manure storage, where both aerobic and anaerobic conditions can exist [5, 12-13]. 
Nitrification occurs under aerobic conditions and follows two steps where ammonium is first oxidized to nitrite, and nitrite is then converted to nitrate, with $\mathrm{N}_{2} \mathrm{O}$ as a by-product [7, 14-16]. Ammonia-oxidizing bacteria are responsible for the production of $\mathrm{N}_{2} \mathrm{O}$ in nitrification [17].

Denitrification is a series of microbe-mediated reactions of the natural microbial process and is an essential part of the nitrogen cycle [18-19]. This anaerobic process is the stepwise reduction of nitrate to nitrogen via nitrite, nitric oxide, and $\mathrm{N}_{2} \mathrm{O}$ [7, 14-16, 20-21].

The $\mathrm{N}_{2} \mathrm{O}: \mathrm{N}_{2}$ ratio produced during denitrification is affected by the presence of anoxia and facultative heterotrophic bacteria capable of denitrification temperatures. The rate of formation and emission of $\mathrm{N}_{2} \mathrm{O}$ varies through time with changes in manure porosity, $\mathrm{pH}$, temperature, moisture, amount of solids, $\mathrm{N}$, and protein content of the manure substrate [1, 22-24]. Manure type may affect $\mathrm{N}_{2} \mathrm{O}$ emissions in several ways, such as the type of $\mathrm{N}$ which changes $\mathrm{N}_{2} \mathrm{O}$ production during nitrification and denitrification. Also, the presence of freely available $\mathrm{C}$, which stimulates denitrification activity and $\mathrm{O}_{2}$ consumption in the soil following, is important $[15,25]$.

The conditions necessary for denitrification also include the availability of reductants such as organic carbon, low availability of degradable carbohydrates, $\mathrm{N}_{2} \mathrm{O}$ reductase activity, and high concentration of $\mathrm{NO}_{3}^{-}, \mathrm{N}_{2} \mathrm{O}$, or NO. This process has been observed at temperatures between 2 and $50^{\circ} \mathrm{C}$, but every $10^{\circ} \mathrm{C}$ rise in substrate temperature may double the rate of denitrification $[15,19$, 26-28].

Microbial production in soils is the dominant nitrous oxide source. $\mathrm{N}_{2} \mathrm{O}$ emissions increase with the use of nitrogen fertilizers [29-30], from manure and urine excreta applied and aerobic and anaerobic degradation of livestock waste in the lagoons and dry manure piles [31]. According to [32], the urea contributed the highest proportion of $\mathrm{N}_{2} \mathrm{O}$ emissions (74.8\%) among the fertilizers. The high $\mathrm{N}_{2} \mathrm{O}$ emission rates generally corresponding with soil conditions are necessary to denitrification, and nitrification is often an essential prerequisite for the conversion of $\mathrm{N}$ fertilizer inputs into soil $\mathrm{NO}_{3}^{-}$[33]. Also, $\mathrm{N}_{2} \mathrm{O}$ emissions are high when $\mathrm{N}$ fertilizers are used for production of concentrates to feed the animals, as well as from excretal returns [29, 34].

Emissions of $\mathrm{N}_{2} \mathrm{O}$ arise both directly and indirectly from more sources on poultry and pig farms [35]. These include the storage deposition of manure and urine and the surface of barn floors. [36] found that maximum concentrations of $\mathrm{N}_{2} \mathrm{O}$ per $1 \mathrm{~kg}$ of $\mathrm{LBW}$ were $30 \%$ lower in the pig-fattening building than in broiler housing.

Nitrous oxide generation in agricultural systems is still not completely understood. Therefore, the emissions reviewed in the current study are dedicated to $\mathrm{N}_{2} \mathrm{O}$ released from housing and solid or liquid wastes application in poultry and pig farms.

\section{Poultry}

The levels of gases in poultry housing have been closely associated with manure management [37]. This process is often characterized by the production and evolution of gases. The decomposition of poultry manure can take place in one of two ways. If oxygen is present then the decay is said to be aerobic, and aerobic disintegration of poultry manure is basically an odourless process that produces stabilized organic matter, some carbon dioxide, and water. On the other hand, most manure practices involve anaerobic decomposition. This is typical of liquid manure handling systems and characteristic of collection pits, holding tanks and storage lagoons [38]. This process is characterized by obnoxious odours and the production of considerable amounts of gases that are hazardous to people and livestock.

Once excreted, poultry manure characteristics change further, depending on various manure management systems of collection, storage, transfer, treatment, and utilization. Most poultry are grown on dirt floors with different bedding materials, which generally need to be very absorbent (to limit the production of ammonia and harmful pathogens) and must have a reasonable drying time [39-41].

Poultry manure may combine bedding with feathers, spilled water and feed, process-generated wastewater (water for flushing gutters, etc.), and dead birds. As a result, the properties of manure differ not only within one species, but also among different types of poultry birds [42]. The increase in manure organic matter accelerates soil metabolism, reduces oxygen, and raises denitrification and $\mathrm{N}_{2} \mathrm{O}$ emissions [43-44]. In contrast, separation of manure solids lowers the organic content of liquid manure, which generally results in lower emissions of $\mathrm{N}_{2} \mathrm{O}$ [44-45].

\section{Housing and Manure Management}

After poultry manure has been excreted by the animals, it quickly begins to undergo some type of microbial decomposition. The principle behind the decomposition is that the complex molecules in the poultry manure are broken down into simpler compounds [38].

Removing manure from storage in a timely manner is an important aspect of overall manure management on a farm. How fast manure is removed from housing and moved to the point of use depends on the size of equipment, e.g., front-end loaders for handling solid manure, the volume of hauling tanks, pump sizes, and the condition of the equipment. The volume of the hauling equipment and the distance manure is transported will determine the time it takes to empty a manure storage tank [46].

Poultry manure is produced during the normal operation of hatcheries, broiler production, and egglaying production. It also occurs in turkey and waterfowl 
production. Since a majority of poultry manure is produced in broiler and layer operations, special attention will be paid to these two specific parts of the poultry industry [38].

Most cage layers are housed in high-rise poultry facilities that are commonly used in egg production [4748]. Manure is collected and stored beneath the bird cages in a pit under the house [40]. A deep pit is used in the cage layer house to minimize odor and insect problems and eliminate water pollution potential. Manure under the cages is typically stored for 6-18 months. These management objectives can be achieved by keeping the manure as dry as possible [39-40, 49]. Another type of house used in layer production is a single-story stair-step house. The cleaning frequency of both types of systems may be based on several factors: the quality of the manure or manure litter in the pit or in the house, the storage space remaining, or the integrator specified clean-out cycle [4050]. Concentrations of harmful gases are commonly high in aviaries and floor housing systems in which manure is not regularly removed [51].

Generally, poultry manure has higher total solids content than most other manures. Dilution with water increases the potential for odor, so handling the manure as a solid is usually preferred. Manure - especially from high-rise and belt-scrape houses - may be handled as solid, liquid, or slurry, whereas manure from a shallowpit layer house is handled as liquid or slurry [42].

Liquid poultry manures (those containing less than $150 \mathrm{~g} . \mathrm{kg}^{-1}$ dry matter) are generated when manure is scraped or flushed into storage reservoirs, such as tanks, detention basins, aerobic or anaerobic lagoons, and oxidation ditches [52-53]. Liquid manure is generally flushed to a manure treatment anaerobic lagoon or a storage pond before it is land-applied as fertilizer, whereas slurry may be stored in an aboveground tank [42, 54].

Manure storage as slurry, manipulating slurry $\mathrm{pH}$ to values lower than 6 and storage as solid manure under anaerobic conditions, help to reduce $\mathrm{N}_{2} \mathrm{O}$ emissions during the manure storage stage. Therefore, a combination of decreased storage time in warm weather and extended winter storage is a viable option in many regions [43-44].

Manure is removed also with a scraper or by flushing to a waste treatment lagoon or waste storage pond. A shallow pit usually means a liquid type of flushing is used every few days, while a deep pit means the manure is handled in solid form and need only be cleaned out once or several times a year.

Most broiler operations result in the production of solid poultry manure, which is referred to as poultry litter or broiler litter. Litter is used in confinement buildings for raising turkeys and other birds. Solid poultry manure contains more than $150 \mathrm{~g}$ dry matter $\mathrm{kg}^{-1}$, which makes them amenable to solid-waste handling systems [52].

Common bedding materials include wood shavings, sawdust, peanut hulls, husk, straw, and other dry, absorbent, low-cost organic materials [55-57]. Sand is also occasionally used as bedding. The final product is a mixture of poultry excreta, spilled feed, feathers, and material used as bedding in poultry operations [40].

An absorbent litter material is usually laid down on the floor and the choice of absorbent litter depends on the needed absorption and commercial availability. The removal of this litter is handled in solid form and can be done after each brood or yearly, or can be left for longer periods [38]. It is normally removed when the birds are moved out [40]. Treating the poultry litter in a biogas digester can substantially reduce emissions while also providing energy [58]. Nitrous oxide losses from poultry litter were generally low compared with $\mathrm{NH}_{3}$ emissions, comprising only about $1.3 \%$ of the gaseous $\mathrm{N}$ losses ( $0.48 \mathrm{~g} \mathrm{~N}$ per bird for $\mathrm{N}_{2} \mathrm{O}$ vs. $30.8 \mathrm{~g} \mathrm{~N}$ per bird for $\left.\mathrm{NH}_{3}\right)$ [59].

Many factors must be considered in successful emission reduction including the time of year, depth of the litter, floor space per bird, feeding practices, disease, the type of floor, ventilation, watering devices, litter amendments, and even the potential fertilizer value of the litter after it is removed from the house. Other factors can be expected to have an influence, such as litter amount (initial amount or regular inputs), flocking density, mortality, temperature, and moisture of outside air [60-62]. Also, additional authors have highlighted the quality of litter and quality of air related to the intensity of ventilation $[41,63]$.

\section{Emissions from Hen and Broiler Housing}

The production of $\mathrm{N}_{2} \mathrm{O}$ from poultry manure depends on faeces composition, the microbes and enzymes involved, and the conditions after excretion [64]. Further, owing to interactions between available $\mathrm{C}$ and $\mathrm{N}$ sources in the correct oxidation form, semi-permeable manure storage covers can enhance $\mathrm{N}_{2} \mathrm{O}$ formation [44, 65-66]. $\mathrm{N}_{2} \mathrm{O}$ emissions are sometimes very difficult to quantify, and low $\mathrm{N}_{2} \mathrm{O}$ concentrations are close to the detection limit of gas analyzers. No $\mathrm{N}_{2} \mathrm{O}$ emission data are available for other types of poultry like turkeys, ducks, geese, etc. The reported $\mathrm{N}_{2} \mathrm{O}$ emissions from poultry vary greatly and have to be judged critically, because the measured concentrations were very low (sometimes only slightly above the ambient concentration of $\mathrm{N}_{2} \mathrm{O}$ ) [67-68].

Over the last two decades, egg production has shifted from deep-pit housing systems (liquid manure management) to manure-belt housing systems (solid manure management). The results of Fournel [69] showed that liquid manure from deep-pit housing systems produces greater emissions of $\mathrm{N}_{2} \mathrm{O}$ than natural and forced dried manure from belt housing systems. The influencing factors appear to be manure removal frequency and the dry matter content of the manure [69]. The emissions from manure storage are largely affected by storage conditions, including ventilation rate, air temperature, and stacking profile $[47,54]$.

Authors [21] analyzed the effect of a tunnel ventilation system on $\mathrm{N}_{2} \mathrm{O}$ losses in a laying hen's farm and found that emissions tended to be higher in winter than in 
summer. The nitrous oxide emission rate was negatively affected by the rate of ventilation. This effect should be the reason that explains the lowest emissions in summer. However, not only the temperature but also the amount of air released from poultry buildings and the content of that air should be new variables in an operating ventilation system [63].

$\mathrm{N}_{2} \mathrm{O}$ emissions were in two buildings for laying hens (a battery system with aerated open manure storage, vertical tiered cages with manure belts with forced air drying) [70]. No significant emissions were registered for $\mathrm{N}_{2} \mathrm{O}$, which was consistently close to zero for both techniques. This depends also on the air exchange. $\mathrm{N}_{2} \mathrm{O}$ concentrations in the enriched cages system with ventilation under the floor of the cages were significantly lower than in the system with the ventilation by the fan placed in the wall [71].

Litter type, management, humidity, and temperature affect gas concentration and emissions from broiler fattening [64, 72]. Results [73] showed that similar indoor thermal environments in all three measured houses were maintained through ventilation management and environmental control. Gaseous and particulate matter concentrations of the enriched colony house were comparable with those of the conventional cage house. In comparison, the aviary house had poorer indoor air quality, especially in wintertime.

Similarly, concentrations of aerial nitrous oxide in broiler, cage, and perchery houses over $24 \mathrm{~h}$ during winter and summer were close to ambient levels [74]. Results of [75] demonstrated that $\mathrm{N}_{2} \mathrm{O}$ emissions from layer chickens were twice as large as for broiler chickens (direct $\mathrm{N}_{2} \mathrm{O}$ emissions of 0.25 vs. $0.17 \mathrm{~kg}$ $\mathrm{CO}_{2} \mathrm{yr}^{-1} \cdot \mathrm{head}^{-1}$, indirect $\mathrm{N}_{2} \mathrm{O}$ emissions of 1.39 vs. $\left.0.68 \mathrm{~kg} \mathrm{CO} \cdot \mathrm{yr}^{-1} \cdot \mathrm{head}^{-1}\right)$. $\mathrm{N}_{2} \mathrm{O}$ concentrations in broiler housing ranged from 0.92 to $8.24 \mathrm{mg} \cdot \mathrm{m}^{-3}$ daily [36]. The increased litter depth increased $\mathrm{N}_{2} \mathrm{O}$ emissions [76]. Authors [77] found very low $\mathrm{N}_{2} \mathrm{O}$ emissions in the housing of broilers, which were on the level of the detecting threshold of their measuring device. It is probable that the very dry litter in this house inhibited the microbial processes necessary to produce both gases [63].

\section{Pigs}

Housing systems often concentrate animals into relatively small areas, which can result in waste disposal problems. The choice of manure management system has a direct influence on space requirements, air quality, pen hygiene, and overall building design. There are more housing types in pig barns, which differ by bedding (deep litter system, straw flow system), floor system (slats, straw flow), and manure deposition (lagoon, manure heap) [28, 78-80].

Collected pig manure can be solid (farmyard manure, deep litter) or liquid form (slurry with typically $1 \%$ to $10 \%$ of dry matter) [6]. Additional bedding or drying is required to handle manure as a solid. Solid manure handling is common for shed and open-lot systems used for swine gestation and finishing. Where these systems are used, solid storage for manure is required, along with facilities for controlling runoff [49]. Slurry and liquid manure can be stored below the partial or full-slotted floor under slat pits or outside tanks in belowground or aboveground storage facilities, or treated in an anaerobic lagoon [36, 49, 81]. In other production systems, effluent from barns is transferred into open anaerobic ponds (lagoons), where the effluent is typically stored for many months with the potential to generate large quantities of emissions [28]. It is estimated that $20-30 \%$ of this waste is stored in lagoons with the subsequent application of the effluent onto soil [82]. If $100 \%$ of digested slurry is utilized as bio-fertilizer, the emissions intensity could be further reduced by 17 times compared to the case without slurry utilization [58].

A primary objective in manure handling is to minimize the accumulation of noxious gases and odors $[79,49]$. Pit ventilation and removing manure from the building to outdoor storage can also reduce odor and gas accumulations within the building. Where odor control is important, an anaerobic waste-treatment lagoon is often recommended [49]. In the USA, hog operations produce more than $14 \mathrm{Tg}$ of manure each year. About $30 \%$ of this manure is stored in anaerobic lagoons before effluent applications on land [83]. Manure affects the balance between $\mathrm{NH}_{3}$ and $\mathrm{N}_{2} \mathrm{O}$ emissions. This interaction may be positive (e.g., both emissions are reduced by an airtight cover during storage and stimulated by composting), or negative (e.g., direct $\mathrm{N}_{2} \mathrm{O}$ emissions from soil will potentially increase if losses of $\mathrm{NH}_{3}$ are prevented during storage or field application) [34].

\section{Emissions from Housing}

As in poultry, $\mathrm{N}_{2} \mathrm{O}$ production is also low in the housing of pigs [77], depending on the density and composition of animal manure. Quality of manure is important, but emissions also depend on many other factors. The fattening period accounts for more than $70 \%$ of total emissions, while the gestation, lactation, and weaning periods each contribute about $10 \%$ of total emissions. Emissions of $\mathrm{N}_{2} \mathrm{O}$ contribute to $2 \%$ of total emissions from pig buildings [11].

An increase of the available area for group-housed gestating sows kept on straw-based deep litter decreased $\mathrm{N}_{2} \mathrm{O}$ emissions, probably due to reduced anaerobic conditions required for their synthesis [84]. The main factors for gas emissions of deep litter pig manure are the initial bulk density of the manure, influencing the free air space and gas exchange, and initial carbon and nitrogen contents [79]. Nitrous oxide emissions per animal unit from deep-litter sheds were negligible in winter and 8.4 g.LU.d ${ }^{-1}$ in summer [85]. With deep litter systems, $\mathrm{N}_{2} \mathrm{O}$ emissions increase regularly in the course of time, principally thanks to the accumulation of dejection and compaction [86-87]. 
The significant effects on $\mathrm{N}_{2} \mathrm{O}$ concentrations in the piggery with slatted housing show ventilation system intensity. Nitrous oxide was reduced by increasing the suction rate, and differences between the low and high ventilation intensities were significant $(0.78 \mathrm{ppm}$ vs. 0.61 ppm) [88].

The release of gases varies during the day. Those variations may explain why the results presented by other authors differed so much. Emissions of $\mathrm{N}_{2} \mathrm{O}$ from partially slatted pig units at the peak hours (13:00-14:00) was twice as high as that observed around 06:00, even though room temperature was kept at around $17^{\circ} \mathrm{C} . \mathrm{N}_{2} \mathrm{O}$ emissions from during a full fattening period of eight weeks were recorded between 8.4 g.pig ${ }^{-1}$ and 9.1 g.pig $^{-1}$ [89].

Total emissions of $\mathrm{N}_{2} \mathrm{O}$ reached the highest values in winter and were influenced especially by high concentrations of gases in the housing area [90]. Similarly, the highest daily emission rates of $\mathrm{N}_{2} \mathrm{O}$ were found in the winter batch, and the lowest emission rates in the summer batch. The calculated emission factors showed $0.17 \mathrm{~kg}$ of $\mathrm{N}_{2} \mathrm{O}$ per animal and year [91]. Whatever the floor type in pig housing, emissions increased from the beginning to the end of the fattening periods by about four times for $\mathrm{N}_{2} \mathrm{O}$ [92].

The effects of slat characteristics on $\mathrm{N}_{2} \mathrm{O}$ emissions have been rarely studied. Generally, the $\mathrm{N}_{2} \mathrm{O}$ emissions are low in slatted floor housing [93-95]. However, it can be assumed that they are of little importance, considering the formation process of these gases. Emissions are associated with the amount of slurry in deep pits and the size of the polluted floor in the housing area [96]. Most important is the frequency of manure removal. Emissions were reduced when underground manure pits were discharged weekly [89].

Protection of the environment should take into account seasonal influences. In winter cycle the total emissions of $\mathrm{N}_{2} \mathrm{O}$ were 1.7 times higher than in summer [97]. For the other work, $\mathrm{N}_{2} \mathrm{O}$ emissions during winter were also higher than in summer [98].

Covers on slurry stores are an effective means of reducing ammonia emissions. Minimizing the stirring of stored slurry (depending on the diet of the pigs and the dry matter content of the slurry) and introducing new slurry below the surface will allow the build-up of a natural crust [99].

Floating crusts on manure storage are environments with intense microbial activity, and microbial processes are governed by the extent of use oxen conditions that are governed by the moisture of the crust. The crust provides a substrate that spans anaerobic and aerobic environments where $\mathrm{N}_{2} \mathrm{O}$ production can occur $[19,34]$. Natural surface crusts may develop into a porous matrix with high $\mathrm{O}_{2}$ availability that harbors an active population of aerobic microorganisms. The occurrence of $\mathrm{NO}_{2}{ }^{-}$and $\mathrm{NO}_{3}{ }^{-}$in the crusts also indicates the presence of actively metabolizing $\mathrm{NH}_{3}{ }^{-}$oxidizing bacteria [66]. An increase in $\mathrm{N}_{2} \mathrm{O}$ emissions in all crusted treatments exposed to anoxia was observed [65]. Authors concluded that covering the stored manure is very efficient for mitigating $\mathrm{NH}_{3}$ emissions, but manure crusts may increase the emissions of $\mathrm{N}_{2} \mathrm{O}$ due to nitrification and subsequent denitrification.

Pig slurry has fewer tendencies to form a natural surface crust than cattle slurry. For this reason it is especially important to cover pig slurry stores in order to avoid $\mathrm{NH}_{3}$ emissions. However, $\mathrm{N}_{2} \mathrm{O}$ emissions release is different. After 200 days of storage under warm conditions, $\mathrm{NH}_{3}$ emissions from uncovered pig slurry were about $40 \%$ higher than emissions from the covered store. Nitrous oxide emissions from uncovered pig slurry reached an $\mathrm{N}_{2} \mathrm{O}$ level of 119 g.m ${ }^{-3}$ after 200 days, compared to 114 g. $\mathrm{m}^{-3}$ from the covered store under warm conditions. After 50 days, $\mathrm{N}_{2} \mathrm{O}$ emissions were 23 and 30 g. $\mathrm{m}^{-3}$ from the uncovered and covered stores, respectively. Under cold conditions, the uncovered store emitted $36 \mathrm{~g} . \mathrm{m}^{-3}$ and the covered store $18 \mathrm{~g} \cdot \mathrm{m}^{-3}$ [100].

\section{Bedding and Floor Comparison}

Several bedding materials were tested in regards to emissions. The most frequent substrates are straw and sawdust. Compared to straw litters, sawdust litters produce more $\mathrm{N}_{2} \mathrm{O}$ [101-103]. It was recorded 3.9 times more higher $\mathrm{N}_{2} \mathrm{O}$ emissions in fattening pigs kept on sawdust litter bedding than straw litter bedding (1.39 g. $\mathrm{d}^{-1}$ vs. 0.36 g.d $\mathrm{d}^{-1}$ per pig) [101]. These results were confirmed by the same authors the next year. Nicks [102] found significantly higher $\mathrm{N}_{2} \mathrm{O}$ emissions in fattening pigs kept on sawdust litter bedding than straw litter bedding (2.09 g. $\mathrm{d}^{-1}$ vs. 0.03 g. $\mathrm{d}^{-1}$ per pig). With the sawdust-based litter, the $\mathrm{N}_{2} \mathrm{O}$ emission was highest during the fattening of the first batch, up to $7 \mathrm{~g}$ per pig per day in the third series of measurements. Over the three fattening periods altogether, the sawdust-based litter produced significantly more $\mathrm{N}_{2} \mathrm{O}\left(+2.06\right.$ g.pig. $\left.\mathrm{d}^{-1}\right)$ [102]

The straw flow systems have been developed combining regular straw supply, sloped floor, and frequent manure scraping. This kind of manure management is efficient for reducing $\mathrm{N}_{2} \mathrm{O}$ emissions, but increases $\mathrm{NH}_{3}$ emissions [86, 92, 104-105]. With fattening pigs kept in a straw flow pen, gaseous emissions were significantly lower for $\mathrm{N}_{2} \mathrm{O}(-55 \%)$ compared to pigs housed on strawbased deep litter [87]. $\mathrm{N}_{2} \mathrm{O}$ emissions were negligible from straw-based litter; they were reduced gradually from one batch to the other, from an average of $3.98 \mathrm{~g} . \mathrm{d}^{-1}$ for batch 1 to an average of $0.70{\mathrm{~g} . \mathrm{d}^{-1}}^{-1}$ for batch 3 [102].

Emissions from the deep litter system were significantly higher than from the slatted floor system for nitrous oxide $(+106 \%)$ [92]. Also, authors [106] confirmed that $\mathrm{N}_{2} \mathrm{O}$ emissions were higher in a deep litter piggery than in building with fully-slatted floor (by $74 \%$, $0.047 \mathrm{~g} \cdot \mathrm{day}^{-1} \mathrm{~kg}^{-1}$ vs. $\left.0.027 \mathrm{~g} \cdot \mathrm{day}^{-1} \mathrm{~kg}^{-1}\right)$. The influence of the type of floor on $\mathrm{N}_{2} \mathrm{O}$ emissions was evaluated in the raising of weaned pigs. Emissions from rearing the weaned pig seem lower with a fully slatted plastic floor system than with deep litter systems. A similar trend was found with sawdust [103].

$\mathrm{N}_{2} \mathrm{O}$ emissions observed during the fattening of pigs kept on the slatted floor were significantly lower than on 
Table $1 . \mathrm{N}_{2} \mathrm{O}$ emission factors from poultry and pig facilities.

360 hens, Lohmann LSL-Lite, 19-27 wks of age; solid manure on the belt, dried manure on the belt, SLR in deep-pit; during 8 wks, $15 \mathrm{~min}$, sampling air, GC; $2.60 \mathrm{~g} \mathrm{yr}^{-1} \mathrm{hen}^{-1}, 2.48 \mathrm{~g} \mathrm{yr}^{-1} \mathrm{hen}^{-1}, 2.78 \mathrm{~g} \mathrm{~N}_{2} \mathrm{O} \mathrm{yr}^{-1} \mathrm{hen}^{-1}$ [69].

Laying hens, floor with straw, $0.017 \mathrm{~kg}_{\text {place }} \mathrm{yr}^{-1}[115]$.

Laying hens, floor with wood shaving, 0.043-0.079 $\mathrm{kg} \mathrm{place}^{-1} \mathrm{yr}^{-1}$ [115].

Laying hens, floor with $3 / 4$ straw and $1 / 4$ wood shaving, $0.155 \mathrm{~kg} \mathrm{place}^{-1} \mathrm{yr}^{-1}$ [115].

Battery CC, 0.95 g.LU ${ }^{-1} \mathrm{~h}^{-1}[115]$.
Battery CC, 0.02-0.15 g.LU $\mathrm{LU}^{-1} \mathrm{~h}^{-1}[69]$.
Floor system, 0.05-0.35 g.LU ${ }^{-1} \mathrm{~h}^{-1}[69]$.

10,000 broilers, from $1.9 \mathrm{ds}$; force ventilated, wood shavings DL; GC, sampling, 35 measured ds; 0.0 g. LU ${ }^{-1}$ day $^{-1}$ [77].

Hens, Lohmann white, 18 to 78 wks; 3 systems on the same farm, manure storage, 2 cycle flocks; CC (196,120 hens, $516 \mathrm{~cm}^{2}$. $\mathrm{hen}^{-1}$, EC (49,754 hens, $752 \mathrm{~cm}^{2}$.hen ${ }^{-1}$, AV (46,762 hens, 1253 to $1257 \mathrm{~cm}^{2}$.hen ${ }^{-1}$ ), PIGM, monitored continually; CC (housing 0.00 g. hen ${ }^{-1} \mathrm{~d}^{-1}$, manure storage 0.03 g. hen ${ }^{-1} \mathrm{~d}^{-1}$ ), EC (housing 0.00 g. hen ${ }^{-1} \mathrm{~d}^{-1}$, manure storage $0.03 \mathrm{~g}$. hen $\left.\mathrm{n}^{-1} \mathrm{~d}^{-1}\right)$, AV ( housing 0.00 g.d $\mathrm{d}^{-1}$, manure storage $0.01 \mathrm{~g}$. hen $\left.{ }^{-1} \mathrm{~d}^{-1}\right)$ [67].

Hens; manure stockpiles, surface area $68 \mathrm{~m}^{2}, 19 \mathrm{~m}^{3}$; uncovered $\left(27820 \mathrm{~kg}, \mathrm{~N} 25.2 \mathrm{~kg} . \mathrm{t}^{-1}\right)$ vs. covered $\left(25120 \mathrm{~kg}, \mathrm{~N} 25.8 \mathrm{~kg} . \mathrm{t}^{-1}\right)$; FTIR, 32 ds; $\mathrm{N}_{2} \mathrm{O}$ emissions below detection [68].

Hens, 52,000 Lohmann-Brown, LBW 2.0 kg; EC, building $17 \mathrm{~m} \mathrm{x} 66 \mathrm{~m}$, EC in 6 rows; AT 18.0 C to 25.4 C (mean 22.4 C),

light:dark 17:7; PIGM; yr average $4.5 \pm 0.28 \mathrm{mg} \cdot \mathrm{d}^{-1} \cdot \mathrm{hen}^{-1}$, summer $3.5 \pm 1.2 \mathrm{mg} \cdot \mathrm{d}^{-1} \cdot \mathrm{hen}^{-1}$, winter $5.2 \pm 1.7 \mathrm{mg} \cdot \mathrm{d}^{-1} \cdot \mathrm{hen}^{-1}$ [21].

10 hens, enriched cage, with vs. without exhausting device, head level, 6 consecutive ds (summer, winter), INNOVA; summer 1.005 $\pm 0.094 \mathrm{mg} \cdot \mathrm{m}^{-3}$ vs. $1.033 \pm 0.116 \mathrm{mg} \cdot \mathrm{m}^{-3}$, winter $1.055 \pm 0.063 \mathrm{mg} \cdot \mathrm{m}^{-3}$ vs. $1.076 \pm 0.061 \mathrm{mg} \cdot \mathrm{m}^{-3}(71)$

Broilers, mechanically ventilated barn $(130 \times 14 \mathrm{~m}, 16$ lateral exhaust fans), summer $(20,100$ birds $)$ vs. winter cycle $(24,000$ birds $)$, PIGM, mean 1.74 mg.h $h^{-1}$.bird ${ }^{-1}$ vs. 2.13 mg.h $h^{-1}$. bird $^{-1} ; 1.73$ g.bird ${ }^{-1}$ vs. 2.07 g.bird ${ }^{-1}$ for cycle [116].

25,000 broilers, concrete floor, chopped straw, ventilated by tunnel and cross two-sided ventilation, PIGM, higher in winter and autumn (from $3.57 \mathrm{mg} . \mathrm{m}^{-3}$ to $\left.8.24 \mathrm{mg} \cdot \mathrm{m}^{-3}\right)$ than in spring and summer $\left(0.92 \mathrm{mg} \cdot \mathrm{m}^{-3}\right.$ to $\left.1.48 \mathrm{mg} \cdot \mathrm{m}^{-3}\right)$ [36].

$21,000$ broilers, tunnel ventilated barn $(100 \times 11 \mathrm{~m})$, air inlets (height $0.38 \mathrm{~m})$ along the sidewalls, exhaust fans (ventilation $2178 \mathrm{~m}^{3}$ $\mathrm{h}^{-1}$ at $0.0 \mathrm{~Pa},-365,5 \mathrm{~m}^{3} \mathrm{~h}^{-1}$ at $50.0 \mathrm{~Pa}$ ), bedding rice hulls; $42 \mathrm{ds}$, PIGM, winter, measured 1, 4, 10, 12, 18, 23, 26, 28, 32, 35 and 40 d; $0.041 \pm 0.002 \mathrm{~g} \mathrm{~d}^{-1}$ bird $^{-1}, 6.7 \pm 0.3 \mathrm{~g} \mathrm{~d}^{-1} \mathrm{LU}^{-1}[61]$.

52,000 broilers, 2 tunnel-ventilated houses (120 x $14.75 \mathrm{~m}, 1700 \mathrm{~m}^{2}$ floor area, 10 fans, clay floor, wood shavings); FTIR, $42 \mathrm{~d}$ age, litter depth $47 \mathrm{~mm}$ vs. $67 \mathrm{~mm}$; 0.30 g.bird ${ }^{-1}$ vs. 0.69 g.bird $^{-1}[76]$

54,000 broilers, 2 tunnel-ventilated houses $\left(120 \times 14.75 \mathrm{~m}, 1700 \mathrm{~m}^{2}\right.$ floor area, 10 fans, clay floor, wood shavings, depth of 40-50 $\mathrm{mm}$ ); CP $19.8 \%$ vs. standard diet (CP $21.3 \%$ ); FTIR, 42 d age; 0.39 g.bird ${ }^{-1}$ vs. 0.42 g.bird $^{-1}$ [76].

57,000 broilers (Cobb), barn ( $93 \mathrm{~m}$ x $29 \mathrm{~m}$, height $4.5 \mathrm{~m}$, sawdust $\left.0.9 \mathrm{~kg} . \mathrm{m}^{2}\right)$, control vs. water additive Biopolym $(3 \mathrm{~g}$ per $100 \mathrm{~kg}$ LBW.d ${ }^{-1}$ ); PIGM, growing cycle, October-November; 0.44 vs. 0.34 g.bird ${ }^{-1}, 0.15$ vs. 0.12 g.h . $^{-1}$ per $500 \mathrm{~kg}$ bedding material [117].

160 fattening pigs; 16 pens, SFS without DMR vs. SFS with DMR; liquid feed (54 \% maize, $22 \%$ grain, and $22 \%$ soy bean); FTIR, June to March; 39.9 g.place ${ }^{-1}$.yr-1 vs. 24.5 g.place ${ }^{-1} . \mathrm{yr}^{-1}[100]$.

Fattening pigs, FSF, 0.02-0.04 kg.place ${ }^{-1} . \mathrm{yr}^{-1}[115]$

Fattening pigs, FSF, $0.15 \mathrm{~kg} \cdot \mathrm{place}^{-1} \cdot \mathrm{yr}^{-1}[115]$.

300 fattening pigs, $25 \mathrm{~kg} \mathrm{LBW}$; partly SF, force ventilated; GC, $17 \mathrm{ds} ; 0.4$ g.LU-1 $\mathrm{d}^{-1}$ [77].

Fattening pigs; 6 housing systems, FSF, DL (wood chips), DL + additives to bedding: Ecozyme, Envirozyme, Bioactive powder, UMS-A-Ferm; PIGM; from 0,8 to 4,95 ppm, no measured emission in FSF, DL average 1.7 g.d $^{-1}-10.0$ g.d d $^{-1}, 0.59$ - 3.44 kg.place ${ }^{-1}$. $\mathrm{yr}^{-1}[80]$.

240 fattening pigs, 2 pens; FSF (0.7 $\mathrm{m}^{2}$.pig-1 $796 \mathrm{~g} \mathrm{LBWG)} \mathrm{vs.} \mathrm{DL} \mathrm{(wood} \mathrm{chips,} 1.0 \mathrm{~m}^{2}$.pig ${ }^{-1}, 806 \mathrm{~g} \mathrm{LBWG}$ ); additives Envirozyme, Ecozyme, Bioactive powder; PIGM, no measured emission in FSF, DL from 0.59 to $3.46 \mathrm{~kg}$.place ${ }^{-1}$. $\mathrm{yr}^{-1}$ [93].

Fattening pigs; without straw; $0.31 \mathrm{~kg} \cdot \mathrm{place}^{-1} \cdot \mathrm{yr}^{-1}[115]$.

Fattening pigs; DL; 1.9-2.4 kg.place ${ }^{-1} \cdot \mathrm{yr}^{-1}[115]$.

108 fattening pigs; LBW from 31 to $110 \mathrm{~kg}, \mathrm{~N} 6.16$ kg.pig ${ }^{-1}$; sawdust DL 40-50 cm, additive Envistim; NOxA, GC, 112 ds; 0.3 g. $\mathrm{h}^{-1}[104]$.

288 fattening pigs, LBW from 26 to $107 \mathrm{~kg}, \mathrm{~N} 6.28 \mathrm{~kg}$. pig $^{-1}$; sawdust DL $70 \mathrm{~cm}$, additive Bactostim; NOxA, GC, 121 ds; 0.2 g.h ${ }^{-1}$ [104].

36 fattening pigs; N 6.7 kg.pig ${ }^{-1}$; FSF, $0.7 \mathrm{~m}^{2}$.pig ${ }^{-1}$; NOxA, GC; 0.0 g.h ${ }^{-1}$ [104].

Fattening pigs; DL; 1.55-3.07 kg.place ${ }^{-1} . \mathrm{yr}^{-1}$ [115]. 
Table 1. Continued.

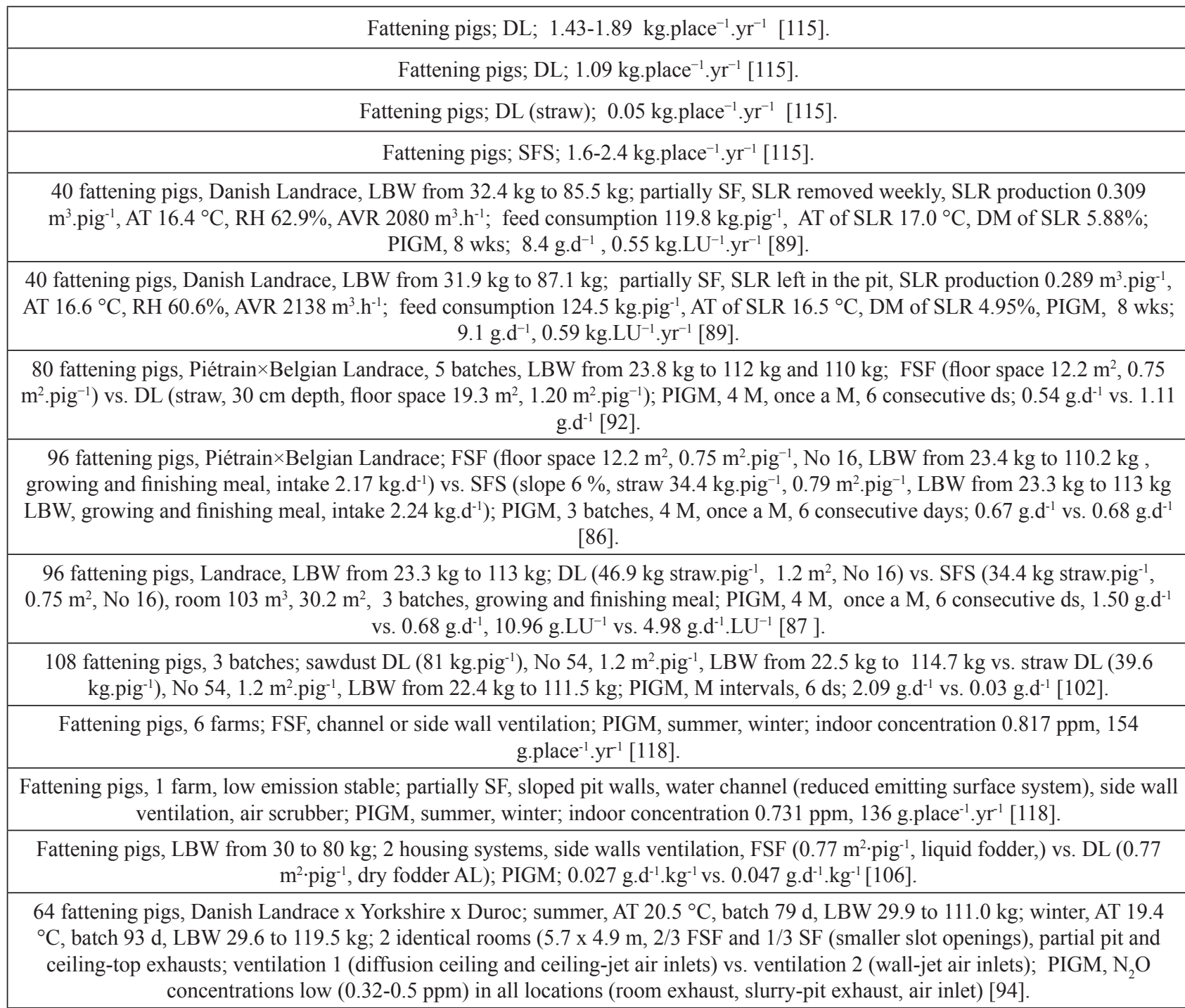

Fattening pigs; partially SF, naturally ventilated, adjustable side walls, anaerobic effluent pond, short hydraulic retention-time tank, housing; winter (No 483, LBW $80.5 \mathrm{~kg}$, LBWG $0.74 \mathrm{~kg} . \mathrm{d}^{-1}$, feed conversion ratio 3.0) vs. summer (No 438, LBW $70.7 \mathrm{~kg}$, LBWG $0.75 \mathrm{~kg} . \mathrm{d}^{-1}$, feed conversion ratio 2.4); FTIR, $30 \mathrm{ds}, \mathrm{N}_{2} \mathrm{O}$ concentrations from the pond and housing close to, or below, the detection limits, retention-time tank $0.001 \mathrm{mg} \cdot \mathrm{LU}^{-1} \cdot \mathrm{d}^{-1}$ vs. $5.9 \mathrm{mg} \cdot \mathrm{LU}^{-1} \cdot \mathrm{d}^{-1} \mathrm{~N}_{2} \mathrm{O}-\mathrm{N}[28]$.

360 fattening pigs, insulated barn, FSF, 3 vacuum fans in the ceiling, max. ventilation rate $21,000 \mathrm{~m}^{3} \cdot \mathrm{h}^{-1} ; \mathrm{PIGM}, \mathrm{N}_{2} \mathrm{O}$ daily ranged from 1.08 to $6.39 \mathrm{mg} \cdot \mathrm{m}^{-3}$, increased concentrations in autumn and winter (3.62 mg. $\mathrm{m}^{-3}$ to $\left.6.39 \mathrm{mg} \cdot \mathrm{m}^{-3}\right)$ [36].

Fattening pigs, SFS, ventilation 3 exhaust ceiling fans, inlet flaps along the sidewalls; summer (348, LBW $25 \mathrm{~kg}$ to $110 \mathrm{~kg}, 105 \mathrm{ds}$ ) vs. winter (352, LBW $25 \mathrm{~kg}$ to $110 \mathrm{~kg}, 121 \mathrm{ds})$; PIGM, 12 min intervals; 0.1 kg.pig ${ }^{-1} \mathrm{yr}^{-1}$ vs. $0.2 \mathrm{~kg}$ pig $^{-1} \mathrm{yr}^{-1}$ [90].

Fattening pigs, SFS, SLR in deep pits, 16 pens, ventilation 3 exhaust ceiling fans, inlet flaps along the sidewalls; summer (356, LBW

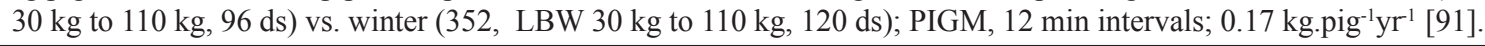

40 gestating sows, Belgian Landrace, parity 4.4 vs. 4.6; straw DL, $2.5 \mathrm{~m}^{2} . \mathrm{sow}^{-1}$, vs. $3.0 \mathrm{~m}^{2} . \mathrm{sow}^{-1}$, LBW from $202.9 \mathrm{~kg}$ to $255.4 \mathrm{~kg}$ vs. $206.2 \mathrm{~kg}$ to $263.2 \mathrm{~kg}$; restricted cereals diet; 4 batches; PIGM, 6 ds (in gestation wks 6, 9, 12); 2.48 g.d $^{-1}$ vs. 1.78 g.d $^{-1}$ [84].

200 weaned pigs, 5 batches, without changing the litter in between batches; sawdust DL ( $\left.30 \mathrm{~cm}, 5 \mathrm{~kg} \cdot \mathrm{pig}^{-1}\right), 0.54 \mathrm{~m}^{2}$.pig ${ }^{-1}, \mathrm{LBW}$ from $7.65 \mathrm{~kg}$ to $24.8 \mathrm{~kg}$ vs. straw DL $\left(30 \mathrm{~cm}, 5 \mathrm{~kg} \cdot \mathrm{pig}^{-1}\right) 0.54 \mathrm{~m}^{2}$. $\mathrm{pig}^{-1}$, LBW from $7.65 \mathrm{~kg}$ to $24.6 \mathrm{~kg}$, transition and post weaning feeds; PIGM, M intervals, 6 ds; 1.39 vs. 0.36 g. $\mathrm{d}^{-1}$ [101].

Weaned pigs, from 3.5 to $11 \mathrm{wks}$, DL, winter (No 958, LBWG $0.53 \mathrm{~kg} . \mathrm{d}^{-1}$, feed conversion ratio 2.1) vs. summer (No 948, LBWG $0.50 \mathrm{~kg} \cdot \mathrm{d}^{-1}$, feed conversion ratio 2.1$), \mathrm{N} 2 \mathrm{O}$ negligible in winter, $8.4 \mathrm{~g} . \mathrm{LU}^{-1} \cdot \mathrm{d}^{-1}[85]$.

20 weaned pigs; FSF vs. DL (straw, $30 \mathrm{~cm}, 8 \mathrm{~kg} \cdot$ pig $^{-1}$ ); LBW from $7.14 \mathrm{~kg}$ to $23.0 \mathrm{~kg}$, LBWG $382.17 \mathrm{~g} . \mathrm{d}^{-1}$; post-weaning feed AL,

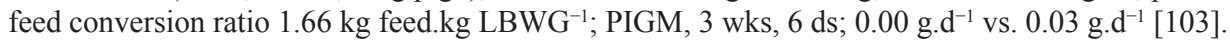

20 weaned pigs, FSF vs. DL (sawdust, $20 \mathrm{~cm}, 26.7 \mathrm{~kg} \cdot$ pig $^{-1}$ ), LBW from $7.14 \mathrm{~kg}$ to $23.0 \mathrm{~kg}$, LBWG 382.17 g.d $\mathrm{d}^{-1}$; post-weaning feed $\mathrm{AL}$, feed conversion ratio $1.66 \mathrm{~kg}$ feed.kg LBWG ${ }^{-1}$, PIGM; 3 wks, 6 ds, 0.01 g.d $\mathrm{d}^{-1}$ vs. $0.32{\mathrm{~g} . \mathrm{d}^{-1}}_{\text {[103]. }}$. 
straw-based deep litter ( 0.54 vs. $1.11 \mathrm{~g}$ per pig per day for $\mathrm{N}_{2} \mathrm{O}$ ) [92]. Mean daily emissions per pig fattened on the slatted floor or on the sloped floor were, respectively, 0.67 and $0.68 \mathrm{~g}$ [86]. Practically no $\mathrm{N}_{2} \mathrm{O}$ emissions were observed from rooms with a slatted floor while the $\mathrm{N}_{2} \mathrm{O}$ emissions were 0.03 and $0.32 \mathrm{~g} \mathrm{~N}_{2} \mathrm{O}-\mathrm{N}^{-\mathrm{d}^{-1}}$ for the straw and sawdust deep litter, respectively [103]. Frequent manure removal seems to be an efficient means for reducing $\mathrm{N}_{2} \mathrm{O}$ emissions from pig buildings for both slatted and bedded floor systems. Manure removal operations may be associated with specific storage conditions and efficient treatment in order to further reduce emissions [11].

\section{Emission from Manure Application}

$\mathrm{N}_{2} \mathrm{O}$ emissions from soil application of animal wastes are a major contributor to total GHG emissions from agriculture [27]. Field application is considered the main source of agricultural $\mathrm{N}_{2} \mathrm{O}$ since all manure types significantly increase microbial production of $\mathrm{N}_{2} \mathrm{O}$ from soils [107]. Soils contribute about $65 \%$ of the total $\mathrm{N}_{2} \mathrm{O}$ produced by terrestrial ecosystems $[1,31]$. Microbial $\mathrm{N}_{2} \mathrm{O}$ production and consumption processes depend on several interacting environmental controls such as $\mathrm{N}$ supply, soil temperature, soil moisture, oxidatione reduction potential, the availability of labile organic compounds, soil type, soil $\mathrm{pH}$, and climate $[30,108]$. Sources of $\mathrm{N}_{2} \mathrm{O}$ emissions are associated with volatilization of landapplied manures [25]. If $100 \%$ digested slurry is utilized as bio-fertilizer, the emissions intensity could be further reduced by 17 times compared to the case without slurry utilization. Treating the poultry litter in a biogas digester can substantially reduce GHG emissions while also providing energy [58].

The variation in the extent of emissions from different types of manure demonstrates the effects of manure properties such as moisture content, total $\mathrm{N}$, and available $\mathrm{N}$ content on emissions generation [109]. $\mathrm{N}_{2} \mathrm{O}$ fluxes were enhanced by the fresh dung but not by urine [110]. Nitrous oxide emission varies with the nature of the effluent applied.

Nitrous oxide emissions from land-applied effluent are highly dynamic and affected by application time, application method, and rainfall or irrigation. However, the dominant environmental factors influencing $\mathrm{N}_{2} \mathrm{O}$ losses include wind speed and temperature [23]. Following field application, infiltration of liquid is influenced by manure organic matter [34].

According to Bell [109], the timing of the application can be critical if significant losses of $\mathrm{N}$ from the soil are to be avoided. Conversely, loss of $\mathrm{N}$ via $\mathrm{N}_{2} \mathrm{O}$ emissions is higher when manure is applied in wet conditions as $\mathrm{N}_{2} \mathrm{O}$ production via denitrification will occur before the crop is able to utilize available $\mathrm{N}$. A proportion of $\mathrm{N}$ that volatilizes as $\mathrm{NH}_{3}$ is considered to be re-emitted as $\mathrm{N}_{2} \mathrm{O}$ upon wet or dry deposition to soils from $\mathrm{N}$ excretion by animals [107].

A number of studies have shown that $\mathrm{N}_{2} \mathrm{O}$ emission rates are highly variable throughout the season, with high rates being associated with grazing and fertilizer application in grazed pastures [1]. The highest losses by denitrification occurred in winter, when soil moisture was at or above field capacity for extended periods.

Season manure application timing (fall vs. spring) had no effect on $\mathrm{N}_{2} \mathrm{O}$ emissions for the annual system. The spring application has been recommended as a means to mitigate $\mathrm{N}_{2} \mathrm{O}$ because it avoids the high $\mathrm{N}_{2} \mathrm{O}$ fluxes related to spring thaw, and $\mathrm{N}$ is supplied to a growing crop that may reduce soil mineral $\mathrm{N}$ availability for nitrifiers and denitrifiers [111].

$\mathrm{N}_{2} \mathrm{O}$ fluxes associated with freeze-thaw events were reduced when manure was applied in spring [112]. However, applying manure in spring also implies higher $\mathrm{N}$ availability when soil temperature is rising and rainfall events are frequent, enhancing soil microbial activity. As a consequence, the highest $\mathrm{N}_{2} \mathrm{O}$ peaks of the experimental period were measured for the spring treatment after significant rainfall events. When broiler litter and layer manure were applied to winter wheat, mean annual $\mathrm{N}_{2} \mathrm{O}$ was greater for autumn $(2 \mathrm{~kg} \mathrm{~N}$ O-N.ha-1) than spring $\left(0.35 \mathrm{~kg} \mathrm{~N}_{2} \mathrm{O}-\mathrm{N} \cdot \mathrm{ha}^{-1}\right)$ applications [109].

Differentiation of $\mathrm{N}_{2} \mathrm{O}$ emission factors, which takes specific factors into account such as $\mathrm{N}$ type and rate and application technique, can improve the quantification of $\mathrm{N}_{2} \mathrm{O}$ emissions from agricultural soils, and is needed to derive most efficient options for mitigation [45]. The emission factors for pig slurry applied to maize land were higher than for cattle slurry; $3.6 \%$ for injected pig slurry and $0.9 \%$ for surface-applied pig slurry [45].

$\mathrm{N}_{2} \mathrm{O}$ emissions are strongly dependent on the method and timing of fertilizer application. Manure incorporation increased $\mathrm{N}_{2} \mathrm{O}$ emissions and yield for the perennial system, but both effects were dependent on interannual weather variability and crop growth [113].

The direct nitrous oxide $\left(\mathrm{N}_{2} \mathrm{O}\right)$ emissions from manure management and from manure applied to soils as an amendment or fertilizer were $2.1 \%$ and $1.3 \%$. Direct $\mathrm{N}_{2} \mathrm{O}$ emissions from manure deposited on soils by grazing livestock were $23.8 \%$ of total GHG emissions [114].

\section{Conclusions}

This review discusses the current knowledge about factors controlling $\mathrm{N}_{2} \mathrm{O}$ emissions in poultry and pig facilities. Substantial variability shows that more data are needed to better quantify emissions from housing and manure management in some measurements. Also, very low concentrations of $\mathrm{N}_{2} \mathrm{O}$ emissions were found (on the level of the detecting thresholds of measuring equipment).

Animal husbandry is a major contributor to global greenhouse gas emissions, in particular nitrous oxide. Therefore, appropriate strategies must be developed for reducing or minimizing emissions. There are various options to reduce $\mathrm{N}_{2} \mathrm{O}$ emissions, but the key option is to improve overall $\mathrm{N}$ efficiency. Therefore, improving animal feed conversion efficiency becomes a major strategy for mitigating $\mathrm{N}_{2} \mathrm{O}$ emissions from these farm 
species. Although several feeding strategies have been tested to decrease GHG emissions, they seem to be ineffective in reducing emissions both significantly and durably.

In general, floor systems for laying hens seem to emit more $\mathrm{N}_{2} \mathrm{O}$ than battery cage or aviary systems. In the broiler housing, very dry litter inhibited the microbial processes needed to produce $\mathrm{N}_{2} \mathrm{O}$. The liquid manure from deep-pit poultry housing systems produces greater emissions of $\mathrm{N}_{2} \mathrm{O}$ than natural and forced dried manure from belt-housing systems. The influencing factors appeared to be the manure removal frequency and the dry matter content of the manure. Emissions are reduced when underground manure pits are discharged weekly.

Slurry and liquid manure handling are more common in larger swine-production facilities. Liquid handling requires less time and labor to collect, transfer, and store manure. The efficient manner to reduce $\mathrm{N}_{2} \mathrm{O}$ emissions from pig buildings for slatted floor systems seems to be a frequent manure removal. It has been concluded that $\mathrm{N}_{2} \mathrm{O}$ emissions from straw and sawdust litter systems of hogs compared with housing on fully slatted floors tend to be higher due to the formation of $\mathrm{N}_{2} \mathrm{O}$. These systems are therefore not recommended. However, welfare on slatted floors is lowered.

The actual rate of $\mathrm{N}_{2} \mathrm{O}$ emissions is highly dependent on the management strategies implemented on a farm. Consequently, improvements in management practices will affect future $\mathrm{N}_{2} \mathrm{O}$ emissions. However, the choice for a housing system is also guided by other factors, such as animal health, performance, and welfare.

From this review of the literature we can see a clear need for the development and use of standard methods for measuring emission rates from hogs and poultry facilities. Accurate emissions data and emission factors are needed for engineering, planning, and regulatory agencies. These data are used for system design and evaluation of the effect of animal densities on surface and ground waters, and atmospheric environments.

Further research must be carried out to check the validity of emission factors and modelling parameters on a national scale. Precise experimental research studies that will measure emissions from housing are needed to establish emission factors for turkey and waterfowl farms, and the effect of management factors on these values.

\section{Acknowledgements}

This article was made possible through APVV projects of the Slovak Research and Development Agency Bratislava (0632-10 and 15-0060), also by the projects AGB 313011 and CEGEZ 26220120073 CEGEZ project 26220120073 supported by the Operational Programme Research and Development fund of the European Regional Development Fund.

\section{Abbreviations}

$\mathrm{AL}=$ ad libitum

$\mathrm{AT}=$ average temperature

$\mathrm{AV}=$ aviary housing

$\mathrm{AVR}=$ average ventilation rate

$\mathrm{CC}=$ conventional cages

$\mathrm{CP}=$ crude protein

$\mathrm{d}=$ day

$\mathrm{DL}=$ deep litter

$\mathrm{DMR}=$ daily manure removal

ds $=$ days

$\mathrm{EC}=$ enriched cages

$\mathrm{FSF}=$ fully statted floor

FTIR = open path Fourier transform infrared spectroscopy $\mathrm{GC}=$ gas chromatography

$\mathrm{GHG}=$ greenhouse gas

$\mathrm{h}=$ hour

LBW = live body weight

$\mathrm{LBWG}=$ gain of live body weight

$\mathrm{LU}=$ live unit $(500 \mathrm{~kg}$ of $\mathrm{LBW})$

$\mathrm{M}=$ month

$\mathrm{MS}=$ manure system

$\mathrm{N}=$ nitrogen

$\mathrm{NH}_{3}=$ ammonium

NOxA $=$ NOx analyser (principle of chemiluminescence)

PIGM $=$ Photoacoustic infrared gas monitor INNOVA

$\mathrm{RH}=$ relative humidity

$\mathrm{SF}=$ slatted floor

$\mathrm{SFS}=$ straw flow system

SLR $=$ slurry

$\mathrm{yr}=$ year

yrs $=$ years

vs. $=$ versus

$\mathrm{wk}=$ week

wks $=$ weeks

\section{References}

1. SAGGAR S., BOLAN N.S., BHANDRAL R., HEDLEY C.B., LUO J. A review of emissions of methane, ammonia and nitrous oxide from animal excreta deposition and farm effluent application in grazed pastures. New Zealand Journal of Agricultural Research 47, 513, 2004.

2. CASEY K.D., BICUDO J.R., SCHMIDT D.R., SINGH A., GAY S.W., GATES R.S., JACOBSON L.D., HOFF S.J. Air Quality and Emissions from Livestock and Poultry Production/Waste Management Systems. In: Animal Agriculture and the Environment, National Center for Manure and Animal Waste Management White Papers. Eds. J.M. Rice, D.F. Caldwell, F.J. Humenik, St Joseph, Michigan, ASABE Pub. Number 913C0306, 1, 2006.

3. LESCHEN J.P., VAN DEN BERG M., WESTHOEK H.J., WITZKE H.P., OENEMA O. Greenhouse gas emission profiles of European livestock sectors. Animal Feed Science and Technology 166-167, 16, 2011.

4. SCHULZE E.D., LUYSSAERT S., CIAIS P., FREIBAUER A., JANSSENS I.A. Importance of methane and nitrous oxide for Europe's terrestrial greenhouse-gas balance. Nature Geoscience 2, 842, 2009. 
5. JOSE V.S., SEJIAN V., BAGATH M., RATNAKARAN A.P., LEES A.M., AL-HOSNI Y.A.S., SULLIVAN M., BHATTA R., GAUGHAN J.B. Modeling of Greenhouse Gas Emission from Livestock. Frontiers in Environmental Science, 14 April 2016, doi: 10.3389/fenvs.2016.00027

6. SCHILS R.L.M., ERIKSEN J., LEDGARD S.F., VELLINGA T.V., KUIKMAN P.J., LUO J., PETERSEN S.O., VELTHOF G.L. Strategies to mitigate nitrous oxide emissions from herbivore production systems. Animal 7, 29, 2013.

7. KLEIN DE C.A.M., ECKARD R.J. Targeted technologies for nitrous oxide abatement from animal agriculture. Australian Journal of Experimental Agriculture 48, 14, 2008.

8. CHIANESE D.S., ROTZ C.A., RICHARD T.L. Simulation of nitrous oxide emissions from dairy farms to assess greenhouse gas reduction strategies. Transactions of the ASABE 52, 1325, 2009.

9. BROUCEK J., CERMAK B. Harmful gases emissions from poultry and possibilities of their reduction. Ekologia, Bratislava 34, 89, 2015.

10. TOIT DU C.J.L., VAN NIEKERK W.A., MEISSNER H.H. Direct methane and nitrous oxide emissions of monogastric livestock in South Africa. South African Journal of Animal Science 43, 362, 2013.

11. PHILIPPE F.X., NICKS B. Review on greenhouse gas emissions from pig houses: Production of carbon dioxide, methane and nitrous oxide by animals and manure. Agriculture, Ecosystems and Environment 199, 10, 2013.

12. CHIANESE D.S., ROTZ C.A., RICHARD, T.L. Simulation of methane emissions from dairy farms to assess greenhouse gas reduction strategies. Transactions of the ASABE 52, 1313, 2009.

13. BELL M.J., HINTON N., CLOY J.M., TOPP C.F.E., REES R.M., CARDENAS L., SCOTT T., WEBSTER C., ASHTON R.W., WHITMORE A.P., WILLIAMS J.R., BALSHAW H., PAINE F., GOULDING K.W.T., CHADWICK D.R. Nitrous oxide emissions from fertilised UK arable soils: Fluxes, emission factors and mitigation. Agriculture, Ecosystems and Environment 212, 134, 2015.

14. OENEMA O., WRAGE N., VELTHOF G., GROENIGEN J.W., DOLFING J., KUIKMAN P. Trends in Global Nitrous Oxide Emissions from Animal Production Systems. Nutrient Cycling in Agroecosystems 72, 51, 2005.

15. KEBREAB E., CLARK K., WAGNER-RIDDLE C., FRANCE J. Methane and nitrous oxide emissions from canadian animal agriculture: A review. Canadian Journal of Animal Science 86, 135, 2006

16. LI C., SALAS W., ZHANG R., KRAUTER C., ROTZ A.C., MITLOEHNER F. Manure-DNDC: a biogeochemical process model for quantifying greenhouse gas and ammonia emissions from livestock manure systems. Nutrient Cycling in Agroecosystems 93, 163, 2012.

17. HU B., TIAN X., ZHAO J., WU P., YANG W., CHEN Y. Theoretical Analysis of Microbial Yield and Pathways Related to $\mathrm{N}_{2} \mathrm{O}$ Production in Nitrification. Polish Journal of Environmental Studies 26, 79, 2017.

18. PAHL O., BURTON C.H., DUNN W., BIDDLESTONE A.J. The source and abatement of nitrous oxide emissions produced from the aerobic treatment of pig slurry to remove surplus nitrogen. Environmental Technology 22, 941, 2001.

19. PHILIPPE F.X., NICKS B. Emissions of ammonia, nitrous oxide and methane from pig houses: Influencing factors and mitigation techniques. In: From the lab to the farm. European Workshop: Reconciling the environment with livestock management, IRSTEA, Rennes, France, 10. 2013.

20. REGAERT D., AUBINET M., MOUREAUX C. Mitigating $\mathrm{N} 2 \mathrm{O}$ emissions from agriculture: A review of the current knowledge on soil system modelling, environmental factors and management practices influencing emissions. Journal of Soil Science and Environmental Management 6, 178, 2015.

21. ALBERDI O., ARRIAGA H., CALVET S., ESTELlÉS F., MERINO P. Ammonia and greenhouse gas emissions from an enriched cage laying hen facility. Biosystems Engineering 144, 1-12, 2016.

22. SAGGAR S., JHA N., DESLIPPE J., BOLAN N.S., LUO J., GILTRAP D.L., KIM D.G., ZAMAN M., TILLMAN R.W. Denitrification and $\mathrm{N}_{2} \mathrm{O}: \mathrm{N}_{2}$ production in temperate grasslands: processes, measurements, modelling and mitigating negative impacts. Science of the Total Environment 456, 136, 2013.

23. LI J., LUO J., SHI Y., HOULBROOKE D., WANG L., LINDSEY S., LI Y. Nitrogen gaseous emissions from farm effluent application to pastures and mitigation measures to reduce the emissions: a review. New Zealand Journal of Agricultural Research 58, 339, 2015.

24. LI J., SHI Y., LUO J., ZAMAN M., HOULBROOKE D., DING W., LEDGARD S., GHANI A. Use of nitrogen process inhibitors for reducing gaseous nitrogen losses from land-applied farm effluents. Biology and Fertility of Soils 50,133, 2014

25. ROSS S.A., CHAGUNDA M.G.G., TOPP C.F.E., ENNOS R. Effect of cattle genotype and feeding regime on greenhouse gas emissions intensity in high producing dairy cows. Livestock Science 170, 158, 2014.

26. BEAUCHAMP E.G. Nitrous oxide emission from agricultural soils. Canadian Journal of Soil Science 77, 113, 1997.

27. MONTES F., MEINEN R., DELL C., ROTZ A., HRISTOV A.N., OH J., WAGHORN G., GERBER P.J., HENDERSON B., MAKKAR H.P.S., DIJKSTRA J. Mitigation of methane and nitrous oxide emissions from animal operations: II. A review of manure management mitigation options. Journal of Animal Science 91, 5070, 2013.

28. MCGAHAN E.J., PHILLIPS F.A., WIEDEMANN S.G., NAYLOR T.A., WARREN B., MURPHY C.M., GRIFFITH D.W.T., DESSERVETTAZ M. Methane, nitrous oxide and ammonia emissions from an Australian piggery with short and long hydraulic retention-time effluent storage. Animal Production Science 56, 1376, 2016.

29. DAVIDSON E.A. The contribution of manure and fertilizer nitrogen to atmospheric nitrous oxide since 1860. Nature Geoscience 2, 659, 2009.

30. BUTTER-BAHL K., BAGGS E.M., DANNENMANN M., KIESE R., ZECHMEISTER-BOLTENSTERN S. Nitrous oxide emissions from soils: how well do we understand the processes and their controls? Philosophical Transactions of the Royal Society B 368, 1621, 2013.

31. BORHAN M.S., MUKHTAR S., CAPAREDA S., RAHMAN S. Greenhouse Gas Emissions from Housing and Manure Management Systems at Confined Livestock Operations, Waste Management - An Integrated Vision, Dr. Luis Fernando Marmolejo Rebellon (Ed.), InTech, 2012. ISBN: 978-953-51-0795-8, DOI: $10.5772 / 51175$.

32. ANEJA V.P., SCHLESINGER W.H., ERISMAN J.W., BEHERA S.N., SHARMA M., BATTYE W. Reactive nitrogen emissions from crop and livestock farming in India. Atmospheric Environment 47, 92, 2012. 
33. ECKARD R.J., GRAINGER C., DE KLEIN, C.A.M. Options for the abatement of methane and nitrous oxide from ruminant production: a review. Livestock Science 130, 47, 2010.

34. PETERSEN S.O., SOMMER S.G. Ammonia and nitrous oxide interactions: roles of manure organic matter management. Animal Feed Science and Technology 166167, 503, 2011.

35. PRATT C., REDDING M., HILL J., SHILTON A., CHUNG M., GUIEYSSE B. Good science for improving policy: greenhouse gas emissions from agricultural manures. Animal Production Science 55, 691, 2014.

36. MIHINA Š., SAUTER M., PALKOVIČOVÁ Z., KARANDUŠOVSKÁ I., BROUČEK J. Concentration of harmful gases in poultry and pig houses. Animal Science Papers and Reports 30, 395, 2012.

37. BARKER J.C. Poultry Layer Production Facility Manure Management: Hig Rise, Deep Pit. North Carolina Cooperative Extension Service, Publication Number: EBAE 131-88, 8 p., 1996.

38. ANONYM. A Review of Poultry Manure Management: Directions for the Future. Agriculture and Agri-Food Canada, Poultry Section, 63, 1990.

39. ANONYM. Northeast Regional Agricultural Engineering Service. NREAS - 132, Poultry Production Handbook, Ithaca, NY, 17 p. 1999.

40. HENRY S.T. Management, Handling, Transfer, Storage and Treatment of Manure and Litter from Poultry Production Facilities. Chapter 4, The Confined Animal Manure Managers program, Clemson Cooperative Extension, West Laurens Street, Laurens, SC 29360, 16 p, 2002. Available online: Dec 7, 2016 from http://www.clemson.edu/ extension/camm/manuals/poultry/pch4_03.pdf

41. KNÍŽATOVÁ M., MIHINA ড̌., BROUČEK J., KARANDUŠOVSKÁ I., MAČUHOVÁ J. The influence of litter age, litter temperature and ventilation rate on ammonia emissions from a broiler rearing facility. Czech Journal of Animal Science 55, 337, 2010.

42. MUKHTAR S. Poultry Production: Manure and Wastewater Management. In: Encyclopedia of Animal Science, Marcel Decker, Inc., 744, 2005.

43. HRISTOV A.N., OH J., FIRKINS J., DIJKSTRA J., KEBREAB E., WAGHORN G., MAKKAR H.P.S., ADESOGAN A.T., YANG W., LEE C., GERBER P.J., HENDERSON B., TRICARICO J.M. Mitigation of methane and nitrous oxide emissions from animal operations: I. A review of enteric methane mitigation options. Journal of Animal Science 91, 5045, 2013.

44. GERBER P.J., HRISTOV A.N., HENDERSON B., MAKKAR H., OH J., LEE C., MEINEN R., MONTES F., OTT T., FIRKINS J., ROTZ A., DELL C., ADESOGAN A.T., YANG W.Z., TRICARICO J.M., KEBREAB E., WAGHORN G., DIJKSTRA J., OOSTING S. Technical options for the mitigation of direct methane and nitrous oxide emissions from livestock: a review. Animal 7, 220, 2013.

45. VELTHOF G.L., MOSQUERA J. The impact of slurry application technique on nitrous oxide emission from agricultural soils. Agriculture, Ecosystems \& Environment 140, 298, 2011.

46. OGEJO J.A. Poultry and Livestock Manure Storage: Management and Safety. Virginia Polytechnic Institute and State University, Virginia Cooperative Extension, Publication 6, 442, 2009.

47. XIN H., GATES R.S., GREEN A.R., MITLOEHNER F.M., MOORE P.A. JR, WATHES C.M. Environmental impacts and sustainability of egg production systems. Poultry Science 90, 263, 2011.

48. ZHAO Y., SHEPHERD T.A., SWANSON J., MENCH J.A., KARCHER D.M., XIN H. Comparative evaluation of three egg production systems: Housing characteristics and management practices. Poultry Science 94, 475, 2014.

49. JAMES R., EASTRIDGE M.L., BROWN L.C., ELDER K.H., FOSTER S.S., HOORMAN J.J., JOYCE M.J., KEENER H.M., MANCL K.M., MONNIN M.J., RAUSCH J.N., SMITH J.M., TUOVINEN O., WATSON M.E., WICKS M.H., WIDMAN N., ZHAO L. Ohio livestock manure management guide, The revised edition of the Ohio Livestock Manure Management Guide, Ohio State University Extension Bulletin 604, Columbus, Ohio. 2001 Fyffe Court, Columbus, OH 43210-1096, 126, 2006.

50. MIHINA S., KAZIMIROVA V., COPLAND T.A. Technology for farm animal husbandry. 1st Issue. Nitra. Slovak Agricultural University 99, 2012.

51. DAVID B., MEJDELL C., MICHEL V., LUND V., MOE R.O. Air Quality in Alternative Housing Systems May Have an Impact on Laying Hen Welfare. Part II-Ammonia. Animals 5, 886, 2015.

52. MOORE P.A. Jr., DANIEL T.C., SHARPLEY A.N., WOOD C.W. Poultry manure management: Environmentally sound options. Journal of Soil and Water Conservation 50, 321, 1995.

53. MOORE P.A. Jr., DANIEL T.C., EDWARDS D.R., MILLER D.M. Evaluation of chemical amendments to reduce ammonia volatilization from poultry litter. Poultry Science 75, 315, 1996.

54. LI D., WATSON C.J., YAN M.J., LALORS., RAFIQUER., HYDE B., LANIGAN G., RICHARDS K.G., HOLDEN N.M., HUMPHREYS J. A review of nitrous oxide mitigation by farm nitrogen management in temperate grassland-based agriculture. Journal of Environmental Management 128, 893, 2013.

55. SWAIN B.K., SUNDARAM R.N.S. Effect of different types of litter material for rearing broilers. British Poultry Science 41, 261, 2000.

56. BOLAN N.S., SZOGI A.A., CHUASAVATHI T., SESHADRI B., ROTHROCK Jr. M.J., PANNEERSELVAM P. Uses and management of poultry litter. World's Poultry Science Journal 66, 673, 2010.

57. BERNHART M., FASINA O.O., FULTON J., WOOD C.W. Compaction of poultry litter. Bioresource Technology 101, 234, 2010.

58. MAINALI B., EMRAN S.B., SILVEIRA S. Greenhouse gas mitigation using poultry litter management techniques in Bangladesh. Energy 127, 155, 2017.

59. MOORE P.A., MILES D., BURNS R., POTE D., BERG K., CHOI I.H. Ammonia emission factors from broiler litter in barns, in storage, and after land application. Journal of Environmental Quality 40, 1395, 2011.

60. MEDA B., HASSOUNA M., AUBERT C., ROBIN P., DOURMAD J.Y. Influence of rearing conditions and manure management practices on ammonia and greenhouse gas emissions from poultry houses. World's Poultry Science Journal 67, 441, 2011.

61. PEREIRA J.L.S. Assessment of ammonia and greenhouse gas emissions from broiler houses in Portugal. Atmospheric Pollution Research 8, 949, 2017.

62. LI S., LI H., XIN H., BURNS R. Particulate matter concentrations and emissions of a high-rise layer house in Iowa. Transaction of ASABE 54, 1093, 2011.

63. KNÍŽATOVÁ M., BROUČEK J., MIHINA Š. Seasonal differences in levels of carbon dioxide and ammonia in 
broiler housing. Slovak Journal of Animal Science 43, 105, 2010.

64. REDDING M.R. Bentonite can decrease ammonia volatilisation losses from poultry litter: laboratory studies. Animal Production Science 53, 1115, 2013.

65. HANSEN R., NIELSEN D., SCHRAMM A., NIELSEN L., REVSBECH N., HANSEN M. Greenhouse gas microbiology in wet and dry straw crust covering pig slurry. Journal of Environmental Quality 38, 1311, 2009.

66. NIELSEN D., SCHRAMM A., REVSBECH N. Oxygen distribution and potential ammonia oxidation in floating liquid manure crusts. Journal of Environmental Quality 39, 1813, 2010.

67. SHEPHERD T.A., ZHAO Y., LI H., STINN J.P., HAYES M.D., XIN H. Environmental assessment of three egg production systems. Part II. Ammonia, greenhouse gas, and particulate matter emissions. Poultry Science 94, 534, 2015.

68. NAYLOR T.A., WIEDEMANN S.G., PHILLIPS F.A., WARREN B., MCGAHAN E.J., MURPHY C.M. Emissions of nitrous oxide, ammonia and methane from Australian layer-hen manure storage with a mitigation strategy applied. Animal Production Science 56, 1367, 2016.

69. FOURNEL S., PELLETIER F., GODBOUT S., LAGACÉ R., FEDDES J. Greenhouse Gas Emissions from Three Cage Layer Housing Systems. Animals 2, 1, 2012.

70. FABBRI C., COSTA A., GUARINO M., VALLI L., MAZZOTTA V. Ammonia, Methane, Nitrous Oxide and Particulate Matter Emissions from Two Different Buildings for Laying Hens. Biosystems Engineering 97, 441, 2007.

71. MIHINA S., BODO S., GALIK R., BROUCEK J. Impact of alternative air exhaustion in housing for poultry on concentration of harmful gases in the air. Agricultural Engineering International, CIGR Journal, Special issue 17, 105, 2015.

72. ROUMELIOTIS, T.S., DIXON, B.J., VAN HEYST, B.J. Characterization of gaseous pollutant and particulate matter emission rates from a commercial broiler operation. Part I: observed trends in emissions. Atmospheric Environment 44, 3770, 2010

73. ZHAO Y., SHEPHERD T.A., LI H., XIN H. Environmental assessment of three egg production systems. Part I: Monitoring system and indoor air quality. Poultry Science 94, 518, 2015.

74. WATHES C.M., HOLDEN M.R., SNEATH R.W., WHITE R.P., PHILLIPS V.R. Concentrations and Emissions Rates of Aerial Ammonia, Nitrous Oxide, Methane, Carbon Dioxide, Dust, and Endotoxin in U.K. Broiler and Layer Houses. British Poultry Science 38, 14, 1997.

75. BOONTIAM W., SHIN Y., CHOI H.L., KUMARI P. Assessment of the Contribution of Poultry and Pig Production to Greenhouse Gas Emissions in South Korea Over the Last 10 Years (2005 through 2014). AsianAustralasian Journal of Animal Sciences 29, 1805, 2016.

76. WIEDEMANN S.G., PHILLIPS F.A., NAYLOR T.A., MCGAHAN E.J., KEANE O.B., WARREN B.R., MURPHY C.M. Nitrous oxide, ammonia and methane from Australian meat chicken houses measured under commercial operating conditions and with mitigation strategies applied. Animal Production Science 56, 1404, 2016.

77. SNEATH R.W., PHILLIPS V.R., DEMMERS T.G.M., BURGESS L.R., SHORT J.L., WELCH S.K. Long term measurements of greenhouse gas emissions from UK livestock buildings. In: Livestock Environment V, Vol. 2, Proceedings of the Fifth International Symposium, Bloomington, Minnesota, 29-31 May. Eds. Robert W.
Bottcher, Steven J. Hoff. Published by ASAE, St. Joseph, Michigan, USA, 146, 1997.

78. WATHES C.M, CHARLES D.R. Livestock housing. UK, CABI Publishing, 428, 1994.

79. WOLTER M., PRAYITNO S., SCHUCHARDT F. Greenhouse gas emission during storage of pig manure on a pilot scale. Bioresource Technology 95, 235, 2004.

80. HOY S. Die Kompoststallhaltung von Mastschweinen Schlußfolgerungen aus dem Vergleich von sieben Systemen. In: IGN-Proceedings Tiergerechte Haltungssysteme für landwirtschaftliche Nutztiere, 23.-25.10.1997, Ed. Roland Weber, Tänikon, Switzerland, FAT-Schriftenreihe 45, 73, 1997.

81. RIGOLOT C, ESPAGNOL S., ROBIN P., HASSOUNA M., BELINE F., PAILLAT J.M., DOURMAD J.Y. Modelling of manure production by pigs and $\mathrm{NH}_{3}, \mathrm{~N}_{2} \mathrm{O}$ and $\mathrm{CH}_{4}$ emissions. Part II: effect of animal housing, manure storage and treatment practices. Animal 4, 1413, 2010.

82. HATFIELD J.L., BRUMM M.C., MELVIN S.W. Swine manure management. Agricultural Uses of Municipal, Animal, and Industrial Byproducts, Chapter 4, Eds. Wright R.J., Kemper W.D., Millner P.D., Power J.F., Korcak R.F. Conservation Research Report No. 44. Washington, D.C., USDA-ARS, 78, 1998

83. SHARPE R.R., HARPER L.A. Ammonia and nitrous oxide emissions from sprinkler irrigation applications of swine effluent. Journal of Environmental Quality 26, 1703, 1997.

84. PHILIPPE F.X., CANART B., LAITAT M., WAVREILLE J., BARTIAUX-THILL N., NICKS B., CABARAUX J.F. Effects of available surface on gaseous emissions from group-housed gestating sows kept on deep litter. Animal 4, 1716, 2010.

85. PHILLIPS F.A., WIEDEMANN S.G., NAYLOR T.A., MCGAHAN E.J., WARREN B.R., MURPHY C.M., PARKES S., WILSON J. Methane, nitrous oxide and ammonia emissions from pigs housed on litter and from stockpiling of spent litter. Animal Production Science 56, 1390, 2016

86. PHILIPPE F.X., LAITAT M., CANART B., VANDENHEEDE M., NICKS B. Gaseous emissions during the fattening of pigs kept either on fully slatted floors or on straw flow. Animal 1, 1515, 2007.

87. PHILIPPE F.X., LAITAT M., NICKS B., CABARAUX J.F. Ammonia and greenhouse gas emissions during the fattening of pigs kept on two types of straw floor. Agriculture, Ecosystems \& Environment 150, 45, 2012.

88. DUBEŇOVÁ, M., ŠIMA, T., GÁLIK, R., MIHINA, $\breve{S}$., VAGAČ, G., BOĎO Š. Reduction of nitrous oxide and carbon dioxide in the pig barn piggery by different ventilation system intensities. Agronomy Research 12, 207, 2014.

89. OSADA T., ROM H.B., DAHL P. Continuous measurement of nitrous oxide and methane emission in pig units by infrared photoacoustic detection. Transactions of the ASAE 41, 1109, 1998.

90. PALKOVIČOVÁ Z., KNÍŽATOVÁ M., MIHINA Š., BROUČEK J., HANUS A. Emissions of greenhouse gases and ammonia from intensive pig breeding. Folia Veterinaria 53, 168, 2009.

91. PALKOVIČOVÁ Z., BROUČEK J., STRMEŇOVÁ A., HANUS A., UHRINČAŤ M., TONGEL P. Emissions of Harmful Gases in Pig Fattening. Ninth International Livestock Environment Symposium Sponsored by ASABE, Valencia Conference Centre, Valencia, Spain, July 8. - 12. 2012, ASABE Conference Presentation, Paper Number: ILES 12-1923, $7 \mathrm{~s}$. 
92. PHILIPPE F.X., LAITAT M., CANART B., VANDENHEEDE M., NICKS B. Comparison of ammonia and greenhouse gas emissions during the fattening of pigs, kept either on fully slatted floor or on deep litter. Livestock Science 111, 144, 2007.

93. HOY S., MÜLLER K., WILlIG R. Ammoniak- und Lachgasemissionen - Auswirkungen verschiedener Tierhaltungssysteme für Mastschweine. Landtechnik 52, 40, 1997.

94. ZONG C., LI H., ZHANG G. Ammonia and greenhouse gas emissions from fattening pig house with two types of partial pit ventilation systems. Agriculture, Ecosystems and Environment 208, 94, 2015.

95. RZEŹNIK W., MIELCAREK P. Greenhouse Gases and Ammonia Emission Factors from Livestock Buildings for Pigs and Dairy Cows. Polish Journal of Environmental Studies 25, 1, 2016.

96. PALKOVIČOVÁ Z., BROUČEK J., HANUS A., TONGEL' P., UHRINČAŤ M., STRMEŇOVÁ A. Effect of season on ammonia emissions in pig fattening. Slovak Journal of Animal Science 45, 53, 2012.

97. PALKOVICOVA Z., KNIZATOVA M., MIHINA S., BROUCEK J., HANUS A. Emissions of hazardous gases from pig housing during winter and summer season. Proceedings of the XVth International Congress of the International Society for Animal Hygiene, Vienna, Editors: Prof. Josef Köfer, Dr. Hermann Schobesberger. First Edition, Brno 2011, Volume III (ISBN 978-80-2630012-0), 1135-1137, 2011.

98. PALKOVICOVA Z., SAUTER M., BROUCEK J., STRMENOVA A., UHRINCAT M., MIHINA, S., HANUS A. Seasonal effect on emissions of ammonia and greenhouse gases in fattening pigs. Emissionen der Tierhaltung; Treibhausgase, Umweltbewertung, Stand der Technik, KTBL-Tagung, 6.-8. Dezember 2011, Kloster Banz, Bad Staffelstein (Germany), KTBL-Schrift 491, 370, 2011.

99. OENEMA O., VELTHOF G., KLIMONT Z., WINIWARTER W. Emissions from agriculture and their control potentials. TSAP Report \#3, Version 2.1. Ed. Markus Amann, November 2012, Service Contract on Monitoring and Assessment of Sectorial Implementation Actions (ENV.C.3/SER/2011/0009), 45 p., 2012.

100. AMON B., KRYVORUCHKO V., FROHLICH M., AMON T., POLLINGER A., MOSENBACHER I., HAUSLEITNER A. Ammonia and greenhouse gas emissions from a straw flow system for fattening pigs: housing and manure storage. Livestock Science 112, 199, 2007.

101. NICKS B., LAITAT M., VANDENHEEDE M., DESIRON A., VERHAEGHE C., CANART B. Emissions of ammonia, nitrous oxide, methane, carbon dioxide and water vapor in the raising of weaned pigs on straw-based and sawdust-based deep litters. Animal Research 52, 299, 2003.

102. NICKS B., LAITAT M., FARNIR F., VANDENHEEDE M., DESIRON A., VERHAEGHE C., CANART B. Gaseous emissions from deep-litter pens with straw or sawdust for fattening pigs. Animal Science 78, 99, 2004.

103. CABARAUX J.F., PHILIPPE F.X., LAITAT M., CANART B., VANDENHEEDE M., NICKS B. Gaseous emissions from weaned pigs raised on different floor systems. Agriculture Ecosystems \& Environment 130, 86, 2009.

104. GROENESTEIN C.M., VAN FAASSEN H.G. Volatilization of ammonia, nitrous oxide and nitric oxide in deep-litter systems for fattening pigs. Journal of Agricultural Engineering Research 65, 269, 1996.

105. PHILIPPE F.X., CABARAUX J.F., NICKS B. Ammonia emissions from pig houses: Influencing factors and mitigation Techniques. Agriculture, Ecosystems and Environment 141, 245, 2011.

106. RZEŹNIK W., MIELCAREK P. Comparison of greenhouse gas emissions during summer from deep litter and fully-slatted piggery. Agricultural Engineering 151, 169, 2014.

107. CROSSON P., SHALLOO L., O'BRIEN D., LANIGAN G.J., FOLEY P.A., BOLAND T.M., KENNY D.A. A review of whole farm systems models of greenhouse gas emissions from beef and dairy cattle production systems. Animal Feed Science and Technology 166-167, 29, 2011.

108. BOUWMAN A.F., BEUSEN A.H.W., GRIFFIOEN J., GROENIGEN VAN J.W., HEFTING M.M., OENEMA O., PUIJENBROEK VAN P.J.T.M., SEITZINGER S., SLOMP, C.P., STEHFEST E. Global trends and uncertainties in terrestrial denitrification and $\mathrm{N}_{2} \mathrm{O}$ emissions. Philosophical Transactions of the Royal Society B 368, 1621, 2013. http://dx.doi.org/10.1098/rstb.2013.0112.

109. BELL M.J., HINTON N.J., CLOY J.M., TOPP C.F.E., REES R.M., WILLIAMS J.R., MISSELBROOK T.H., CHADWICK D.R. How do emission rates and emission factors for nitrous oxide and ammonia vary with manure type and time of application in a Scottish farmland? Geoderma 264, 81, 2016.

110. HARGREAVES P.R., REES R.M., HORGAN G.W., BALL B.C. Size and Persistence of Nitrous Oxide HotSpots in Grazed and Ungrazed Grassland. Environment and Natural Resources Research 5, 1, 2015.

111. CHADWICK D., SOMMER S., THORMAN R., FANGUEIRO D., CARDENAS L., AMON B., MISSELBROOK T. Manure management: implications for greenhouse gas emissions. Animal Feed Science and Technology 166-167, 514, 2011.

112. ABALOS D., BROWN S.E., VANDERZAAG A.C., GORDON R.J., DUNFIELD K.E., WAGNER-RIDDLE C. Micrometeorological measurements over 3 years reveal differences in $\mathrm{N}_{2} \mathrm{O}$ emissions between annual and perennial crops. Global Change Biology 22, 1244, 2016.

113. WEBB J., THORMAN R., FERNANDA-ALLER M., JACKSON D. Emission factors for ammonia and nitrous oxide emissions following immediate manure incorporation on two contrasting soil types. Atmospheric Environment 82, 280, 2014.

114. CORNEJO C., WILKIE A.C. Greenhouse gas emissions and biogas potential from livestock in Ecuador. Energy for Sustainable Development 14, 256, 2010.

115. JUNGBLUTH T., HARTUNG E., BROSE G. Greenhouse emissions from animal houses and manure stores. Nutrients Cycling Agroecosystem 60, 133, 2001.

116. CALVET S., CAMBRA-LOPEZ M., ESTELLES F., TORRES A.G. Characterization of gas emissions from a mediterranean broiler farm. Poultry Science 90, 534, 2011.

117. BOBRUTZKI VON K., AMMON C., BERG W., FIEDLER M. Quantification of nitrogen balance components in a commercial broiler barn. Czech Journal of Animal Science 58, 566, 2013.

118. RANSBEECK VAN N., LANGENHOVE VAN H., WEYENBERG VAN S., MAES D., DEMEYER P. Typical indoor concentrations and emission rates of particulate matter at building level: a case study to setup a measuring strategy for pig fattening facilities. Biosystems Engineering 111, 280, 2012. 